\title{
How valid FRAX is in different countries?
}

\author{
Farklı ülkelerde FRAX ne kadar geçerlidir?
}

\author{
O. Şahap Atik, M.D. \\ Department of Orthopedics and Traumatology, Medical Faculty of Gazi University, Ankara, Turkey
}

Recently, WHO developed FRAX, a tool used for the osteoporotic fracture risk assessment. ${ }^{[1]}$ However, it is thought that this tool has serious limitations. In previous articles, we mentioned that Greece was defined as a "high-risk country", whereas Turkey, in the same neighborhood, was accepted in "the lowest risk group". We believe that FRAX is not beneficial for our patients in Turkey, due to probably outdated and insufficient data. ${ }^{[2,3]}$ The results are incorrect for some other countries too. Bolland et al. ${ }^{[4]}$ found substantial differences in the estimated 10-year risk of major osteoporotic fracture between the FRAX-United Kingdom and FRAX-New Zealand tools, despite similar estimates of hip fracture risk from the two tools, and similar epidemiology of osteoporotic fractures in the two countries. The authors also mentioned that FRAX developers (Kanis et al. $\left.{ }^{[5]}\right)$ considered that a validation study could only be conducted in a very large cohort over a very long follow-up duration, must include participants with a very wide range of fracture risk (including large numbers of untreated patients at high risk of fracture), having completed follow-up.

Kanis et al. ${ }^{[5]}$ reported that the ratio of age-adjusted hip fracture continue to arise in several countries (e.g. Japan, China, Turkey, Mexico and Hispanic Americans from California). They mentioned that a large number of information was available in the majority of countries; thus, both national and regional estimates performed several years ago might not be representative of current risks. Kanis et al. ${ }^{[5]}$ also modified FRAX-Turkey using the data of a recent study ${ }^{[6]}$ and defined Turkey as a "high-risk country", which was accepted in "the lowest risk group" previously.

Currently, the question is that "Is this replacement from one extreme to another extreme in a short period of time right?" When we consider the statement of "a validation study can only be conducted in a very large cohort over a very long follow-up, must include participants with a very wide range of fracture risk (including large numbers of untreated patients at high risk of fracture) and having completed follow-up", we do not have any suitable cohorts in Turkey which can meet such stringent criteria, to the best of our knowledge.

In conclusion, we still think that FRAX tool has serious limitations for some countries.

\section{REFERENCES}

1. Available from: http://www.shef.ac.uk/FRAX/tool.jsp

2. Atik OS. Osteoporotic fracture risk assessment. Eklem Hastalik Cerrahisi 2008;19:100.

3. Atik OS. Is DXA the gold standard? Eklem Hastalik Cerrahisi 2011;22:63.

4. Bolland MJ, Grey A, Gamble G, Reid IR. Comment on Kanis et al.: Pitfalls in the external validation of FRAX. Osteoporos Int 2013;24:389-90. doi: 10.1007/s00198-012-1977-y.

5. Kanis JA, Odén A, McCloskey EV, Johansson H, Wahl DA, Cooper C. A systematic review of hip fracture incidence and probability of fracture worldwide. Osteoporos Int 2012;23:2239-56.

6. Tuzun S, Eskiyurt N, Akarirmak U, Saridogan M, Senocak $\mathrm{M}$, Johansson $\mathrm{H}$, et al. Incidence of hip fracture and prevalence of osteoporosis in Turkey: the FRACTURK study. Osteoporos Int 2012;23:949-55. doi: 10.1007/s00198011-1655-5.

\footnotetext{
- Correspondence: O. Şahap Atik, M.D. Gazi Üniversitesi Tıp Fakültesi Ortopedi ve Travmatoloji Anabilim Dalı, 06500 Beşevler, Ankara, Turkey. Tel: +90 312 - 2025528 Fax: +90 312 - 2129008 e-mail: satikmd@gmail.com
} 